Linguistik Terapan 15 (1) (2018): 8-14

Jurnal Linguistik Terapan Pascasarjana

Available online http://jurnal.unimed.ac.id/2018/index.php/JLTUnimed

\title{
MAINTAINING BAHASA ACEH IN KEUDE KUPI AMONG TEENAGERS IN MEDAN
}

\author{
Emalia Amna \\ Anni Holila Pulungan \\ Rahmad Husein
}

Diterima Januari 2018; Disetujui Pebruari 2018; Dipublikasikan April 2018

\section{ABSTRACT}

This study focuses specifically on investigating the maintenance of Bahasa Aceh by Acehnese teenagers in keude kupi in Medan. It employs qualitative research method and applies a case study design. The subjects were ten Acehnese Teenagers in keude kupi in Medan. The instruments used for this study were observation, interview and document gathering. The observation was applied to get the data about the language they used in the keude kupi. The interview was applied to get the data for answering the three questions of this study; factors affecting Bahasa Aceh maintenance, the manners done by the teenagers and the reasons for maintaining the language in keude kupi. While the documentation needed to give a visual data about the subjects and site of the study. The data were analysed by using Ethnography Method, proposed by Spradley. It has been found that there were some factors lead to the maintenance of Bahasa Aceh, they are: language attitude, parents' role, environment, visiting homeland continuously and intra-marriage. The maintenance of Bahasa Aceh was done by keep using it to other Acehnese, read the Acehnese online or printed media, and watch or listen to the Acehnese entertainment. In maintaining their mother language, the teenagers' reasons were not only about showing their identity, help their community to progress and achieving self-esteem and/or selfpride, but also to create the feel-like-home situation, since using the language with the same Acehnese peers makes them feel closer and bound.

Keywords: Language Maintenance, Bahasa Aceh, Teenagers, Keude Kupi

How to Cite: Amna, Emalia (2018).Maintaining Bahasa Aceh in Keude Kupi Among Teenagers in Medan. Jurnal Linguistik Terapan Pascasarjana Unimed, 15 (1): 8-14

ISSN 2407-7410

\section{INTRODUCTION}

Languages are supposed to be the important part of lives in the society which transmits the values of life. Indonesia has 707 languages spoken around 221 million inhabitants. It means that approximately 
ten percent of the number of languages in the world are in Indonesia. Linguists predict that half of the world's languages will be extinct. In Indonesia, according to Moseley (2010) in his book The Atlas of the World's Languages in Danger, there are 146 languages are endangered and 12 languages have become extinct.

Linguistic diversity is a pillar of cultural diversity. Therefore, the extinction that occurred at a language means a loss of cultural treasures. To overcome the local languages endangered, it needs to be maintained. As Holmes (2001: 63) stated that where language is considered as an important symbol of a minority group's identity, the language is likely to be maintained longer. The maintenance of a heritage language is vital for the self-identity and esteem of its speaker (Corson, 2001: 174). Therefore, a language needs to be protected, preserved and maintained.

Anies Baswedan, the former Minister of Education and Culture of the Republic of Indonesia (Kompas, 2015) when opening the 2015 Congress of Civilization Aceh stated that the demise of the local language is as a result of the public that are no longer accustomed to use the language. In addition, Saragih (2010) stresses the importance of safe in maintaining a local language. The indigenous language needs to be safe for their contribution on the enrichment of Bahasa Indonesia. $\mathrm{H}$. Steinhauer (1994) states that on the national level, a very important factor that diminishes the prestige of regional languages is the prevalence of diglossia, whereby Indonesian functions as the national, supra-ethnic, official language, whereas the regional languages are used for unofficial intra-ethnic communication and local cultural events.

According to Hadi Sahputra (2014) in his study about The Maintainance of Acehnese by Its Speakers at the Eastern Coast of Serdang Bedagai Regency, states that the existence of the speakers of Acehnese are at the level of safe but in their children or their generation is at the level of unsafe and it leads to the language shift to a dominant language, that is, Indonesian language as well as Malay language and Javanese language or other local language which are the major population, which dominate the use of vernacular. As Juliana (2012) in her study states that create a socially integrated population of active speakers of the language is the good effort in maintaining the indigenous or local language. For Acehnese, keude kupi (coffee shop) is much more than a place to drink a coffee. It is easy to find customers who attend the keude kupi in Medan communicate using Bahasa Aceh to each other, both adults and teenagers. The use of Bahasa Aceh is not only when they are discussing their villages or personal issues, but also other common things, such as the political issues, sports and many other things. Therefore, the researcher intends to know the factors lead to the maintainance of Bahasa Aceh by the Acehnese teenagers in keude kupi in Medan; the way Acehnese teenagers maintain their mother language in the keude kupi; and the reaosns of maintainaning Bahasa Aceh in Keude kupi.

\section{REVIEW OF RELATED LITERATURE \\ LANGUAGE MAINTENANCE}


Language maintenance is defined as the condition of a language especially a minority language which is used by particular group or speakers of a society. Trask (1998: 26) bold that the continued use of a language by its speakers, especially in circumstances in which it is under pressure from mother language. Yet languages have no existence without people, the process of language maintenance involves different levels, individuals, community, nation, and linguists (through bilingual education, and language planning, for example), (Baker 2006; Pakir, 1994). While Hoffman (1991:186), when a community does not maintain its language, but gradually adopts another one, we talk about language shift while language maintenance refers to a situation where members of a community try to keep the languages they have always used.

\section{FACTORS OF LANGUAGE MAINTENANCE}

Holmes (2001: 63) states briefly that there are some other factors that can maintain a language, they are:

\section{Environment}

Tennant \& Reyhner (1995), hold that the influences of environment in language maintenance in the case of the Maintenance and Renewing Native Language American Indian Language, environment as the one of the factor in language maintenance.

\section{The Language Attitude}

Some factors that affect language maintenance and shift include social aspects, attitudes of group of people in society, the use of the language in the community, and language policy regulated by government (Grosjean, 1982).

\section{Parents' Role}

Yamamoto (2001: 7) notes that when the minority language speaking parents adhere to the minority language, she/he can provide the child with the maximum quantity of exposure to the language, ensure the child's exposure to the widest range vocabulary and grammatical structures of the language, allow the language to develop appropriately with age through natural interaction, and detect under developer areas of the language.

\section{Visiting Homeland Continuosly}

Interaction and communication with other family in homeland may increase the children to maintain their local language to their ability in communicating and interacting by using the language in their daily lives.

\section{Intra-marriage}

Holmes (2001) states the intra mariage help to maintain the language of the minority. It means that someone who mariage with the same tribe help maintenance the language, because they have the same language and culture, so they have the high prestige to their language and culture.

\section{The Effort in Language Maintenance}

According to Berman (2011), there are some ways or manners can be done by the young speakers to maintain their mother language. The ways are: (1) Speak the language with the people of the same 
culture; (2) Read the articles or publications in ones mother language, will benefit you to know how the language is written; (3) Watch the movie. When one watches a movie and/or listens to the music in his/her native language, he is not only acquiring or learning the language but also the culture.

\section{RESEARCH METHOD}

Qualitative research was applied as the design for this research. The data of this study were the utterances of Bahasa Aceh used in the conversation of the participants gotten during observations. The interviews' results that cover information about the factors of maintaining Bahasa Aceh, the ways or strategies in maintaining the language, and the reasons of maintaining the language in keude kupi were also the data to answer the three research questions. The data were collected by observation, interview and making documentations.

\section{FINDINGS AND DISCUSSIONS}

\section{A. Findings}

Based on the results of data analysis, the findings of this study are formulated as follows:

1. There are five factors lead the teenagers of Aceh maintain Bahasa Aceh in keude kupi, they are; attitude, parents' role, environment, frequently visits their hometown and intra-marriage family. The positive attitudes of the speakers help the language to be maintained well, even when the speakers are minority. The role of the parents encourages their children to keep using their mother language when interacting with people who speak the same mother language. While the supportive environment, such as keude kupi, make the teenagers feel closer to each other when they speak the same language. Visiting their hometown regularly helps them reuse their native language, and comes from the intra-marriage family makes them exposed more to Bahasa Aceh in their daily activities.

2. The maintenance of Bahasa Aceh occurred in their daily conversation and also in their cultural organization during being together or meeting in the keude kupi. Reading the article written in Acehnese and watching the Acehnese or listening to the Acehnese music are also be their strategies to maintain their mother language. As they not only gain the knowledge of the language use, but also the culture value presented in the movie.

3. The maintenance happened because those teenagers feel bound tightly and closer when they can speak the same language, which is their mother language. Honor and self-esteem are also gained by using Bahasa Aceh as their daily language in keude kupi. In adition, the teenagers were member of the IPTR (Youth of Acehnese Organization), they use to speak Aceh when hold the meeting or when interact with each other. It may help their organization to progress. Feeling far from the hometown makes the teenager wants to create a feel-like-home situation. Unconsciously, it makes them maintain Bahasa Aceh by speaking Acehnese every time they meet each other's. 


\section{Discussions}

\section{Factors Lead to the Bahasa Aceh Maintenance}

After analyzing the data, there are some important points to be discussed regarding to the objectives of the study. It is found that there are some factors affecting the maintenance of Bahasa Aceh in keude kupi, they are; having positive attitude, parents' role, environment, visiting homeland continuously and intra-marriage. As stated by Schiffman (2008), no one factor can be singled out as the only factor in successful or unsuccessful language maintenance; usually a complex of factors. The teenagers' attitude toward their mother tongue encourages them to keep maintaining the language. When they realize the important of the culture identity, they try to keep it safe. Holmes (2000) contends that language shift tends to be slower among communities where a minority language is highly valued. That is, positive attitudes toward a language will help its speakers make every effort to maintain it. Positive attitudes might support effects to use the minority language in variety of domains and also help people resist to pressure from the majority group to switch to their language (Holmes, 1992: 68). While negative attitudes appear to have played an important role in the endangerment of many indegenous languages. A negative attitude toward the language can accelerate the language shift, it can be occuring when an ethnic language is not highly valued and it is not seen as a symbol of identity.

Parents' role becomes the next factor that influences those teenagers in maintaining their mother language. Zhang (2008) says that parents showed different positive attitudes towards the language; some parents regard their mother language as an important resource that the children could take advantage of their academic advancement and future career. Studies have identified parental support and involvement as perhaps the most important factor related to successful maintenance of the mother language (Arriagada, 2005; Oh \& Fuligini, 2007; Suarez, 2002, 2007). Studies have reported that the communication at home between children and parents in these families is frequently if not usually conducted in the mother language (Han, 2003). Thus parents alone seem to greatly influence maintenance of the language (Oh \& Fuligini, 2007; Park \& Sarkar, 2007). The Acehnese teenagers are mostly motivated and encouraged to speak Bahasa Aceh with their peers in the public area, such as keude kupi by seeing their parents doing it so. Environment is the other factor that affects the maintenance of Bahasa Aceh. Keude kupi provides the supportive environment and atmosphere for the teenagers to keep using their mother language. A strong Aceh culture in the place encourages the teenagers who have migrated from their home town to keep maintaining the language, which is one of the cultural products. 


\section{The Efforts Done by the Acehnese Teenagers}

Keep using Bahasa Aceh as their daily language when speaking with other Acehnese people is one of the way the teenagers do to maintain their mother language. Being in the Youth of Acehnese Organization and keep using Bahasa Aceh when holding the meeting or communicate with each other may help them maintain their mother language. They also frequent access the news portal presented in Bahasa Aceh since the Acehnese printed media is hardly found in Medan. In addition, the teenagers are enjoy the Acehnese comedy entertainment plays in the keude kupi. They found it interesting and is helpful to retain their mother language. Kosonen (2005) stated that literacy helps the minority preserve their indigenous language. Literacy or able to read and write in the case of indigenous language helps the native to maintain their mother tongue and transfer it to the next generations. This is in line with the Australian Ministry of Education language policy launched in 2012 (Toa: 2017), which stressed the importance of the vernacular languages.

\section{The Reasons for Maintain Bahasa Aceh in Keude Kupi}

A sense of belonging, feeling closer and the bounding make the teenagers keep using Bahasa Aceh to each other in every occasion when they meet up in the keude kupi, which ultimately succeeded in maintaining their mother tongue. In addition, besides of the heritage reasons, by keep using the language when communicating with other Acehnese teenagers, they will gain honor and self-esteem. Creating a feel-like-home situation is another reason of the teenager for keep maintaining their mother language. It is noted that hearing the surrounding speak their mother language create a feel-like-home situation for them.

\section{CONCLUSIONS}

The study which is concerned with the maintaining of Bahasa Aceh among Acehnese teenagers in Keude kupi in Medan was aimed to describing the factors that support the process of maintenance of Bahasa Aceh, the way of how it was realized and the reasons for why those teenagers keep maintaining their mother tongue in the public area, such as keude kupi. The reasons for maintaining Bahasa Aceh in Keude kupi were to show their identity as the young generation of Aceh and to gain honor and self-esteem. Making a progress to their community, or in this case is IPTR also became one of their reasons for maintain Bahasa Aceh.

\section{REFERENCES}

Berman, R. 2011. Attitudes towards languages and cultures of young Polish adolescents in Iceland. Online Journal on Pedagogy and Education, University of Iceland. Málfríður, 26(1), 1518.

Brenzinger, M. 2005. The Endangerment of Language Diversity: Responsibilities for Speech Communities and Linguists. Journal of Al-Maghrib al-Ifrîqî. Vol. 6 :63-80. 
Brown, G., and Yule, G. 1989. Discourse Analysis. New York: Cambridge University Press.

Corson, D. 2001. Language Diversity and Education. New Jersey: Lawrence Erlbaum Associates.

Hoffmann. 2009. Endangered Languages, Linguistics, and Culture: Researching and Reviving the Unami Language of the Lenape. A thesis Anthropology and Linguistic. Bryn Mawr College.

Holmes, J. 1992. An Introduction to Sociolinguistics, Second Edition. London: Pearson.

. 2001. An Introduction to Sociolinguistic: Insight into Human Geography Learning About Language. USA: Longman.

Kosonen, K. (2005). Education in local languages: Policy and practice in Southeast Asia. First languages first: Community-based literacy programmes for minority language contexts in Asia. Bangkok: UNESCO Bangkok

Moseley, C. 2010. Atlas of the World's Languages in Danger, 3rd edn. Paris, UNESCO Publishing

Saragih, A. 2010. Revitalisasi Bahasa Daerah dalam Konteks Sosial Indonesia. Makalah Seminar Internasional Hari Bahasa Ibu: Menyelamatkan Bahasa Ibu sebagai Kekayaan Budaya. Bandung. 19-20 Februari 2010.

Schiffman, H. 1998. German-American Language Maintenance Effort. Handout for Linguistics 540, Language Policy.

Nurhayati, E. 2013.Strategi Pemertahanan Bahasa Jawa di Provinsi Daerah Istimewa Yogyakarta.JurnalPenelitianBahasa, SastradanPengajarannya, Vol. 12, No. 1.

Spradley, J. P. 2007. Metode Etnografi. A Translation by Misbah Zulfa Elizabeth from The Etnographic Interview. Yogyakarta: Tiara Wacana . 1980. Participant Observation. New York: Holt, Rinehart \& Winston 1979. The Ethnographic Interview. New York: Holt, Rinehart \& Winston

Steinhauer, H. 1994. The Indonesian language situation and linguistics; Prospects and possibilities. Bijdragen tot de Taal-, Land- en Volkenkunde 150. pp 755-784.

Turjoman. 2017. Language Maintenance and Core Values Among $2^{\text {nd }}$ Generation Arabs in the USA. International Journal of Applied Linguistics and English Literature Vol. 6, No. 3.

Quintan, J. 2015. Sociolinguistics: Language Maintenance, Shift, and Death. http://www.slideshare.net/jholyq/sociolinguisticslanguage-maintenance-shift-and-death. Retrieved on February 15, 2017 